\title{
Effects of Ethanolic Extract of Curcuma Longa on Cardiac Biomarkers of Doxorubicin-Induced Rats
}

\author{
Lydia Ernawati Rahayu, Linda Chiuman, Chrismis Novalinda Ginting, Sahna Ferdinand Ginting \\ Faculty of Medicine, Universitas Prima Indonesia, Medan, Indonesia
}

\begin{abstract}
Cardiotoxicity is a condition where damages caused by toxic chemical exposure are observed in heart and blood vessels. Doxorubicin is the most common chemotherapy agents for various types of cancer therapy. However, doxorubicin is converted into doxorubicinol known to trigger cardiac disfunctions and release of several cardiac biomarkers, such as CK-MB and LDH. Turmeric is known to be an alternative medical treatment that has the effect of neutralizing oxidative stress. This study aimed to evaluate CK-MB and LDH levels in doxorubicin-induced rats $(20 \mathrm{mg} / \mathrm{kgBW})$ that received turmeric ethanolic extract from curcuma. This was an experimental study conducted in February 2020 in the Faculty of Pharmacy Universitas Sumatera Utara. The rats were divided into six group and each group consisted of wistar albino male rats. The groups were normal (CMC-Na), positive control (Vitamin E 1\%+Dox $20 \mathrm{mg} / \mathrm{kgBW}$ ), negative control (Dox $20 \mathrm{mg} / \mathrm{kgBW}$ ), treatment I (EEC $100 \mathrm{mg} / \mathrm{kgBW}+$ Dox $20 \mathrm{mg} /$ $\mathrm{kgBW}$ ), treatment II (EEC $300 \mathrm{mg} / \mathrm{kgBW}+$ Dox $20 \mathrm{mg} / \mathrm{kgBW}$ ), and treatment III (EEC $500 \mathrm{mg} / \mathrm{kgBW}+$ Dox $15 \mathrm{mg} /$ $\mathrm{kgBW}$ ). Doxorubicin was given $5 \mathrm{mg} / \mathrm{kgBW}$ once a week for four weeks. Results showed that the groups that received $100 \mathrm{mg} / \mathrm{kg} \mathrm{BW}, 300 \mathrm{mg} / \mathrm{kgBW}$, and $500 \mathrm{mg} / \mathrm{kgBW}$ of turmeric ethanol extract demonstrated a reducing effect on the biomarkers of cardiac damage, i.e. CK-MB and LDH. Statistically, serum CK-MB and LDH levels at dose $500 \mathrm{mg} / \mathrm{kgBW}$ showed no significant differences $(\mathrm{p}>0.05)$ with the normal and positive treatment group. In conclusion, turmeric has a cardioprotective effect.
\end{abstract}

Keywords: Cardiotoxicity, CK-MB, LDH

\section{Pengaruh Kardioprotektif Ekstrak Etanol Curcuma Longa pada Tikus yang Diinduksi Doxorubicin}

\begin{abstract}
Abstrak
Kardiotoksisitas adalah kondisi terjadinya jantung dan pembuluh darah akibat paparan kimia. Doxorubicin diubah menjadi doxorubicinol yang diketahui menyebabkan gangguan fungsi jantung dan pelepasan biomarker jantung sseperti CK-MB dan LDH. Kunyit dikenal sebagai pengobatan alternatif yang memiliki efek menetralkan stres oksidatif. Penelitian ini dilakukan pada Februari 2020 di Fakultas Farmasi Universitas Sumatera Utara. Tujuan penelitian ini adalah mengevaluasi kadar CK-MB dan LDH pada tikus yang diberi ekstrak etanol kunyit yang diinduksi doksorubisin (20 mg/kgbb). Penelitian dibagi menjadi enam kelompok dan tiap-tiap kelompok terdiri atas 4 ekor tikus wistar albino jantan: normal (CMC-Na), kontrol positif (Vitamin E 1\%+Dox $20 \mathrm{mg} / \mathrm{kgBB}$ ), kontrol negatif (Dox $20 \mathrm{mg} / \mathrm{kgBB}$ ), group I (EEC $100 \mathrm{mg} / \mathrm{kgBB}+$ Dox $20 \mathrm{mg} / \mathrm{kgBB}$ ), group II (EEC $300 \mathrm{mg} / \mathrm{kgBB}+$ Dox 20 $\mathrm{mg} / \mathrm{kgBB}$ ), dan group III (EEC $500 \mathrm{mg} / \mathrm{kgBB}+$ Dox $15 \mathrm{mg} / \mathrm{kgBB}$ ). Doxorubicin $5 \mathrm{mg} / \mathrm{kgBB}$ diberikan 4 kali. Hasil penelitian menunjukkan bahwa kelompok yang diberi ekstrak etanol kunyit dengan dosis $100 \mathrm{mg} / \mathrm{kgBB}, 300 \mathrm{mg} /$ $\mathrm{kgbb}, 500 \mathrm{mg} / \mathrm{kgBB}$ memiliki efek penurunan biomarker kerusakan jantung yaitu CK-MB dan LDH. Berdasar atas hasil uji statistik kadar CK-MB dan LDH serum pada dosis $500 \mathrm{mg} / \mathrm{kgBB}$ tidak terdapat perbedaan yang bermakna $(p>0,05)$ dengan kelompok normal dan positif, dapat disimpulkan bahwa kunyit memiliki efek kardioprotektif.
\end{abstract}

Kata kunci : CK-MB, LDH, kardiotoksisitas

Corresponding Author: Linda Chiuman, Faculty of Medicine, Universitas Prima Indonesia, Jalan Belanga No. 1 Simpang Ayahanda Medan, North Sumatra, Indonesia, Email: lindachiuman@unprimdn.ac.id 


\section{Introduction}

Doxorubicin (DOX) is used as one of the most common chemotherapy agents for various types of cancer therapy, which is derived from the class of antibiotics anthracyclines. ${ }^{1}$ In clinical use, this class of antibiotics has limitations due to side effects, which can cause cardiotoxicity that is quite severe in cancer patients, both acute and chronic, depending on the dose of administration. $^{2}$

The side effects of doxorubicin are irreversible in chronic use, including the formation of cardiomyopathy, congestive heart failure, nephrotoxic, and hepatotoxic. ${ }^{3,4}$ As reported by Wattanapitayakul, ${ }^{5}$ the risk of using doxorubicin causes side effects in normal tissue, especially in the heart, and causes the suppression of the immune system. The tissue in the heart organ has an active metabolic. Still, this organ has a low antioxidant ability compared to other organs in the human body. Hence, the heart is very vulnerable to damage caused by free radicals, one of which is doxorubicin. ${ }^{2}$ The biological picture is shown in general, and the effect of using doxorubicin is apoptosis or necrosis. ${ }^{6}$

In a study conducted by Clafshenkel et al., administering doxorubicin $4 \mathrm{mg} / \mathrm{kg}$ body weight in animal mice that is carried out once a week for four weeks intraperitoneally (IP) increases cardiac fibrosis when compared to a control group not administered with doxorubicin. Because of doxorubicin's effects, we need an active compound that can protect the heart organ (cardioprotective), which cardioprotective compounds can provide excellent antiinflammatory and antioxidant effects.

In research conducted in vitro, curcumin compounds contained in turmeric are cytotoxic, where the content of curcumin can inhibit the proliferation of cancer cells, and can also reduce pain or wound size from cancer. Therefore, turmeric is very likely to be used as an antiinflammatory and is very useful for anti-cancer therapy. The potential of turmeric as a medicinal plant can be further investigated so that its utilization as traditional medicine can be further maximized without adverse side effects. ${ }^{8}$

Based on the description above, the longterm cancer therapy with doxorubicin often causes multiorgan damage, one of which can cause cardiotoxicity. Turmeric plants (Curcuma longa Linn = Tumeric) with a content that is rich in curcuminoid (curcumin) have properties as a potent free radical reducer, thus encouraging researchers to test the effectiveness of ethanolic extract of Curcuma (EEC) on experimental animals induced by doxorubicin in the heart organ. The parameters measured are CKMB (Creatine kinase-MB) and LDH (Lactate dehydrogenase) as biomarkers.

\section{Methods}

Microplate Reader, $\mathrm{pH}$ meter (OHAUS Starter300 Portable) Beaker glass (IWAKI CTE33), Multiskan Go Reader (Thermo Fisher Scientific 1510), analytic measure, Eppendorf tube, vial $1 \mathrm{~mL}$, Spatula, Micropipet (1-10 $\mu \mathrm{L}, 50-200 \mu \mathrm{L}, 100-$ $1000 \mu \mathrm{L})$ (Eppendorf), Thermometer, automated plate washer, Tumeric, Vitamin E, Ketamine (Sigma P-4417), Doxorubicin (Merck 109057), and CMC-Na (Sigma P-4417) were used in this study. Animals used in the research were rats (Rattus norvegicus), Wistar males of 150-200 $\mathrm{g}$ (each group consisted of 4 rats). Before the study commenced, the animal test was adjusted for one week with the room temperature (22$25^{\circ} \mathrm{C}$ ) under the cycle of 12 hours light/dark, with the provision of food and drinking water ad libitum. Ethics Commission from health and science commission, University Prima Indonesia approved this study (No. 012/KEPK/UNPRI/ II/2020). The present study was conducted in the Faculty of Pharmacy, Universitas Sumatera Utara, and the serum was analyzed at the North Sumatera Regional Health Laboratory.

Air-dried Curcuma Longa (800 g) was extracted with $90 \%$ ethanol $(12 \mathrm{~L})$ three times ( $2 \mathrm{~h}$ each) using a soxhlet under reflux. The ethanol extract was concentrated under vacuum to give a crude extract (150 g). Qualitative analytical phytochemical screening of the ethanol Curcuma extract method consisted of identification of phenol, steroids/terpenoids, saponins, flavonoids, tannin, and alkaloids.

In vivo, an experiment was conducted by using 24 Wistar rats (Rattus norvegicus) male and weight 150-200 g, divided into six groups, and each group consisted of 4 rats. The groups were Normal (Suspension Na-CMC), Negative control (male Wistar rats [Rattus norvegicus] induced by doxorubicin $20 \mathrm{mg} / \mathrm{kgBW}$ ), Positive control (male Wistar rats [Rattus norvegicus] induced by doxorubicin $20 \mathrm{mg} / \mathrm{kgBW}$ + Vitamin E 1\%), Group I (male Wistar rats [Rattus norvegicus] induced by doxorubicin $20 \mathrm{mg} / \mathrm{kgBW}+$ EEC 100 $\mathrm{mg} / \mathrm{kgBW}$ ), Group II (male Wistar rats [Rattus norvegicus] male induced by doxorubicin $20 \mathrm{mg} /$ $\mathrm{kgBW}+\mathrm{EEC} 300 \mathrm{mg} / \mathrm{kgBW}$ ), and Group III (male Wistar rats [Rattus norvegicus] induced by 
doxorubicin $20 \mathrm{mg} / \mathrm{kgBW}+$ EEC $500 \mathrm{mg} / \mathrm{kgBW}$ )

Rats were induced by doxorubicin with an accumulative dose of $20 \mathrm{mg} / \mathrm{kgBW}$ for over 21 days, with a $5 \mathrm{mg} / \mathrm{kgBW}$ dose once a week. Before treatment, the rats were given the extract with a dose of $100 \mathrm{mg} / \mathrm{kgBW}, 300 \mathrm{mg} / \mathrm{kgBW}$, and $500 \mathrm{mg} / \mathrm{kgBW}$ for 21 days. On the last day of treatment, the rats were not given any food or water for 18 hours before undergoing surgery for the animal test. Rats were administered with ketamine $70 \mathrm{mg} / \mathrm{kgBW}$ intraperitoneally, and then underwent surgery. Thoracic dissection was performed and $3 \mathrm{~mL}$ of blood was collected and then transferred a microtube to be centrifuged for 10 minutes at 3,000-4,000 rpm of speed until it was separated into serum, and supernatant. Next, $1 \mathrm{~mL}$ of serum was collected and put into microtubes to be stored in the refrigerator at a temperature of $4^{\circ} \mathrm{C}$ for determination of CK-MB and LDH. Measurement of the CK-MB and LDH levels was performed by following the method [9]. As much as $50 \mu \mathrm{l}$ samples and $500 \mu \mathrm{l}$ of CKMB reagent/LDH was mixed in a test tube. The initial absorbance was then read after 1 minute at a wavelength of $340 \mathrm{~nm}$. Next, the absorbance was measured again after 1,2 , and 3 minutes. Test analysis was carried out using one-way analysis of variance (ANOVA), followed by Post Hoc Test using the Tukey HSD test. In this study, $\mathrm{P}<0.05$ was considered as a statistical significance. Data analysis was performed using the IBM SPSS 20.

\section{Results}

The results of phytochemical screening qualitatively in Curcuma extract were shown in the Table 1. Phytochemical screening of ethanol extract of Curcuma showed the positive result of flavonoids, tannins, saponins, glycosides, alkaloids, and steroids. In this study, an examination of CK-MB from the blood of rats

\section{Table 1 Results of Phytochemical Screening of Extract Curcuma}

\begin{tabular}{lcc}
\hline \multicolumn{1}{c}{ Chemical Component } & & Result \\
\hline Tanin & + & \\
Saponin & + \\
Flavonoid & + \\
Steroid & + \\
Glikosida & + \\
Alkoloid & + \\
\hline
\end{tabular}

Table 2 CK-MB Level

\begin{tabular}{lc}
\hline \multicolumn{1}{c}{ Doses } & Mean CK-MB \pm SD (U/L) \\
\hline Normal & $323.63 \pm 5.00^{\#^{*}}$ \\
Negative control & $997.53 \pm 7.44$ \\
Positif control & $442.23 \pm 3.19^{\#^{*}}$ \\
Group I & $751.73 \pm 12.67$ \\
Group II & $427.03 \pm 2.46$ \\
Group III & $379.32 \pm 34.57^{\#^{*}}$ \\
\hline
\end{tabular}

Post tukey test $\mathrm{p}<0.05$ \#: has a significant different with negative group; $p>0.05 *$ : No significant different with normal

was carried out. The results of serum CK-MB obtained can be seen in Table 2 .

Based on Table 2, it is known that the average serum CK-MB value for the normal group was still within the normal range of $323.63 \pm 5.00 \mathrm{U} / \mathrm{L}$.

The negative control group (doxorubicin induction) had an average serum CK-MB of $997.53 \pm 7.44 \mathrm{U} / \mathrm{L}$. The positive control group had an average serum CK-MB of $442.23 \pm 3.19 \mathrm{U} / \mathrm{L}$ while the treatment group I had a serum CK-MB value of $751.73 \pm 12.67 \mathrm{U} / \mathrm{L}$. The treatment group II had a serum CK-MB value of $427.03 \pm 2.46 \mathrm{U} / \mathrm{L}$ and the treatment group III had a serum value of $379.32 \pm 34.57 \mathrm{U} / \mathrm{L}$.

Based on the table, it was revealed that the average serum CK-MB in the most extensive treatment group was $751.73 \pm 12.67 \mathrm{U} / \mathrm{L}$ in treatment group I. Furthermore, the ordinary serum CK-MB in the smallest treatment group is $379.32 \pm 34.57 \mathrm{U} / \mathrm{L}$ in treatment group III, as can be seen in Figure 1.

In this study, an examination of LDH in the blood of rats was carried out. The results of serum LDH obtained can be seen in Table 3 . Based on the table, it is known that the average serum LDH value for the normal group is still within the normal range of $551.36 \pm 5.29 \mathrm{U} / \mathrm{L}$.

Table 3 LDH Level

\begin{tabular}{lc}
\hline \multicolumn{1}{c}{ Doses } & $\begin{array}{c}\text { Mean LDH } \pm \text { SD } \\
\text { (U/L) }\end{array}$ \\
\hline Normal & $551.36 \pm 5.29^{\#^{*}}$ \\
Negative control & $2791.36 \pm 2.05$ \\
Positif control & $651.78 \pm 2.07^{\#^{*}}$ \\
Group I & $1382.01 \pm 78.06$ \\
Group II & $847.46 \pm 2.80$ \\
Group III & $731.21 \pm 2.05^{\#^{*}}$ \\
\hline
\end{tabular}

Post tukey test $\mathrm{p}<0.05$; \#: has a significant different with negative group; $>>0.05$; *: No significant different with normal 


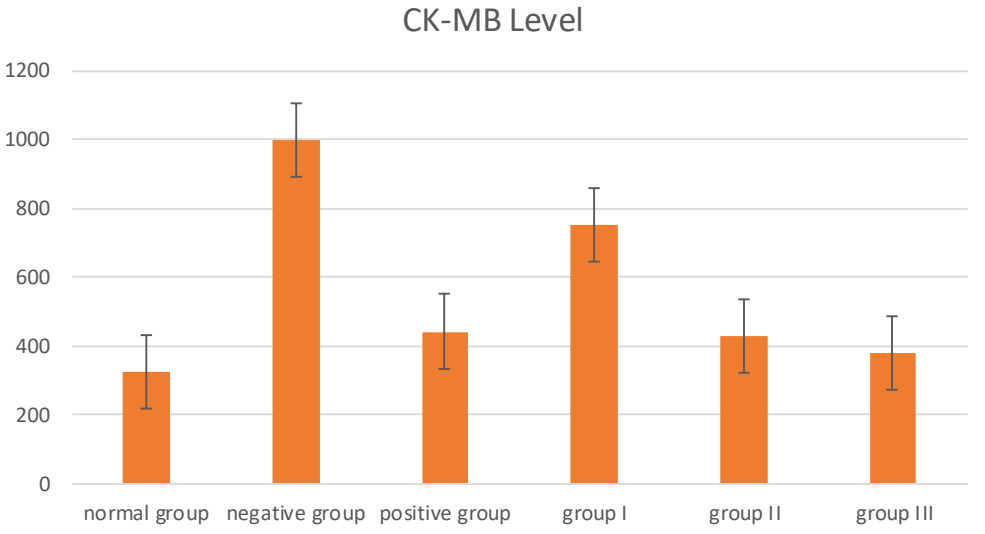

Figure 1 CK-MB Level

The positive control group (doxorubicin induction) had an average serum LDH of 2153.66 U/L. Treatment group I had a serum LDH value of $1245 \mathrm{U} / \mathrm{L}$. Treatment group II had a serum LDH value of $916.33 \mathrm{U} / \mathrm{L}$. Treatment group III had a serum value of $839.33 \mathrm{U} / \mathrm{L}$, and a positive control group using Vitamin $\mathrm{E}$ as a comparison had an average serum LDH of $784 \mathrm{U} / \mathrm{L}$.

Based on the Table 3, it is known that the average serum LDH in the most extensive treatment group is $1245 \mathrm{U} / \mathrm{L}$ in treatment group I. Furthermore, the ordinary serum LDH in the smallest treatment group is $839.33 \mathrm{U} / \mathrm{L}$ in treatment group III.

\section{Discussion}

Based on statistical test results, serum CKMB levels in the normal group had significant differences $(p<0.05)$ with the negative control treatment group, treatment group I, treatment group II, and treatment group II and did not have significant differences $(\mathrm{p}>0.05)$ with a positive control group with vitamin e supplementation. Serum levels of CK-MB negative control group had significant differences $(\mathrm{p}<0.05)$ with the negative control treatment group, treatment group I, treatment group II, and treatment group II, and the positive control group with vitamin e supplementation.

Serum levels of CK-MB positive control group presented significant differences $(\mathrm{p}<0.05)$ with the negative control treatment group, the normal group, and the treatment group I and insignificant difference $(p>0.05)$ with the positive control group, treatment group II, and treatment group II. Serum levels of CK-MB in treatment group I had a significant difference $(\mathrm{p}<0.05)$ with the negative control group, normal group, positive control

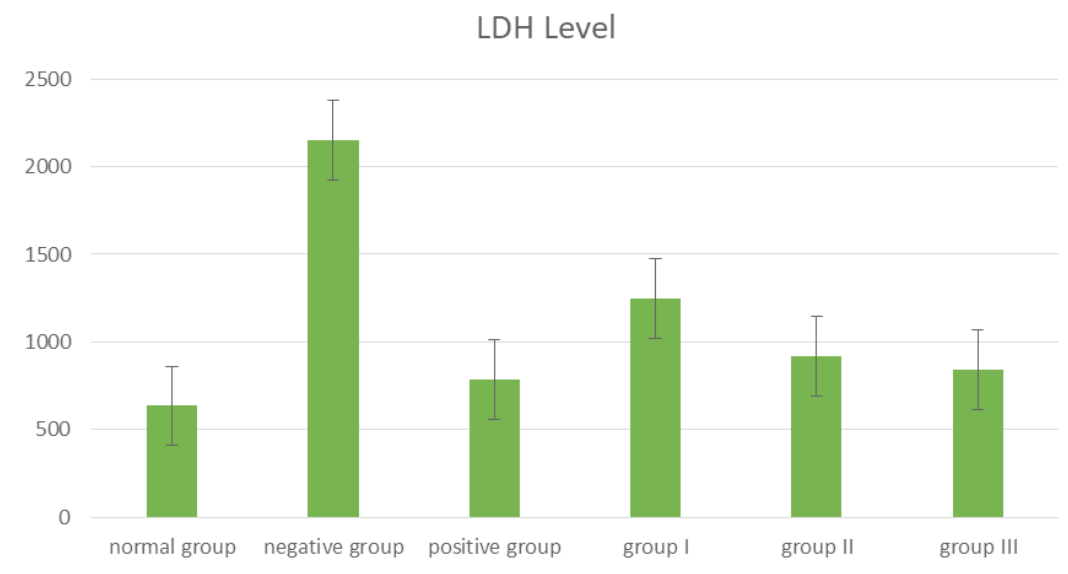

Figure 2 LDH 
group, treatment group I, and treatment group II. Serum levels of CK-MB treatment group II, with significant differences $(\mathrm{p}<0.05)$ with the normal group, negative group, and treatment group I, without significant difference $(\mathrm{p}>0.05)$ with a positive control group and treatment group III. Serum levels of CK-MB in treatment group III had a significant difference $(p<0.05)$ with the normal group, negative group, and treatment group I, with no significant differences ( $p>0.05$ ) with a positive control group and treatment group II.

Based on statistical test results, serum LDH levels in the normal group had a significant difference $(p<0.05)$ with the negative control treatment group, treatment group I, treatment group II, and treatment group II, without significant difference $(p>0.05)$ with the group positive control with vitamin e supplementation. Serum LDH levels in the negative control group had significant differences $(\mathrm{p}<0.05)$ with the negative control treatment group, treatment group I, treatment group II, and treatment group II, and the positive control group with vitamin e supplementation.

Serum LDH levels in the positive control group had significant differences $(\mathrm{p}<0.05)$ with the negative control treatment group, the normal group, and the treatment group I, without significant difference $(p>0.05)$ with the positive control group, treatment group II, and the treatment group II. Serum LDH levels in the treatment group I had a significant difference $(p<0.05)$ with the negative control group, normal control group, positive control group, treatment group I, and treatment group II. Serum LDH level in treatment group II had a significant difference $(p<0.05)$ with the normal group, the negative group, and the treatment group I, without significant difference $(p>0.05)$ with the positive control group and treatment group III. Serum LDH levels in the treatment group III had a significant difference $(p<0.05)$ with the normal group, the negative group, and the treatment group I, without significant difference $(p>0.05)$ with the positive control group and treatment group II. Tumeric and saffron extract was used to prevent cardiac toxicity caused by doxorubicin. This study identified the cardioprotective effect of turmeric on doxorubicin-induced cardiotoxicity in mice. Curcumin has been used in traditional medicine since it has a cardioprotective, hepatoprotective, and chemopreventive effect on various cancers. Also, it can reduce lipid levels. ${ }^{10}$ The mechanism of cardiotoxicity caused by doxorubicin is known from this study. However, a large amount of evidence points towards the formation of oxygen free radicals, which can damage cells by lipid peroxidation. ${ }^{11}$ Damage to heart tissue may be caused by increased oxidative stress and the depletion of similar antioxidants in mice previously reported. ${ }^{12}$

Giving turmeric increases antioxidant levels. Thus, it prevents heart damage, mainly due to the antioxidant action of curcumin. Turmeric ethanol extract prevents doxorubicin-induced histological changes in rat heart tissue by restoring endogenous antioxidant activity or as an antioxidant or both. ${ }^{13}$

In this study, it can be concluded that cardiotoxicity caused by doxorubicin is related to oxidative stress. Anti-proliferation, antiinitiation, and scavenging properties of free radicals from turmeric can increase myocardial integrity and reduce cardiac toxicity. ${ }^{14}$

Turmeric is proven to be cardioprotective, which can be attributed to its strong antioxidant properties. This research shows that turmeric can be considered a potentially useful candidate combined with Dox to limit free radical-mediated organ injury. ${ }^{15}$

In conclusion, the ethanol extract of Curcuma has a cardioprotective effect by reducing the level of heart damage biomarkers, namely LDH and CKMB. Curcuma was proven to be cardioprotective, which can be potentially developed as herbal medicine as additional therapy while using doxorubicin.

\section{References}

1. Septiana AT, Handayani I, Winarsi H. Aktivitas antioksidan dan sifat fisikokimia madu temulawak (curcuma zanthorrhiza roxb) yang ditambah ekstrak jahe (zingiber officinale rosc). Jurnal Aplikasi Teknologi Pangan. 2019;8(4):155-60.

2. Marques-Aleixo I, Santos-Alves E, Oliveira PJ, Moreira PI, Magalhães J, Ascensão A. The beneficial role of exercise in mitigating doxorubicin-induced Mitochondrionopathy. Biochimica et Biophysica Acta (BBA)-reviews on cancer. Elsevier BV. 2018;1869(2):18999.

3. Economopoulou P, Kentepozidis N, Kotsakis A, Kapiris I. Cancer therapy and cardiovascular risk: focus on bevacizumab. Cancer Management and Research. Informa UK Limited. 2015:4(10):179-80.

4. Ghazali MT, Arsito PN. Uji aktivitas hepatoprotektif teh hijau kombucha pada tikus putih yang diinduksi parasetamol. 
Jurnal Ilmiah Farmasi Universitas Islam Indonesia (Islamic University of Indonesia). 2012:9(2):20.

5. Comparison of obesity prevalence, based on body mass index, waist circumference and waist/hip ratio, in patients with coronary artery disease (which method should be used?). Atherosclerosis Supplements. Elsevier BV; 2002. p. 210.

6. Ewer MS, Ewer SM. Cardiotoxicity of anticancer treatments: what the cardiologist needs to know. Nat Rev Cardiol. 2010;7(10): 564-75.

7. Clafshenkel WP, King TL, Kotlarczyk MP, Cline JM, Foster WG, Davis VL, et al. Morinda citrifolia (Noni) Juice augments mammary gland differentiation and reduces mammary tumor growth in mice expressing the unactivated c-erbB2 transgene. Evid Based Complement Alternat Med. 2012;2(8):1-15

8. Idris $\mathrm{H}$, Nurmansyah N. Efektivitas ekstrak etanol beberapa tanaman obat sebagai bahan baku fungisida nabati untuk mengendalikan Colletotrichum gloeosporioides. Buletin Penelitian Tanaman Rempah dan Obat. 2016;26(2):117.

9. Imbaby S, Ewais M, Essawy S, Farag N. Cardioprotective effects of curcumin and nebivolol against doxorubicin-induced cardiac toxicity in rats. Hum Exp Toxicol. 2014:3(38):800-13.

10. Gunes S, Sahinturk V, Karasati P, Sahin IK, Ayhanci A. Cardioprotective effect of selenium against cyclophosphamide- induced cardiotoxicity in rats. Biol Trace Elem Res. 2017;177(1):107-14.

11. Namdari M, Eatemadi A. Cardioprotective effects of curcumin-loaded magnetic hydrogel nanocomposite (nanocurcumin) against doxorubicin-induced cardiac toxicity in rat cardiomyocyte cell lines. Artif Cells Nanomed Biotechnol. 2017;45(4):731-9.

12. Yang Y, Duan W, Lin Y, Yi W, Liang Z, Yan J, et al. SIRT1 activation by curcumin pretreatment attenuates mitochondrial oxidative damage induced by myocardial ischemia reperfusion injury. Free Radic Biol Med. 2013;65:667-79.

13. Duan J, Mansour HM, Zhang Y, Deng $\mathrm{X}$, Chen Y, Wang J, et al. Reversion of multidrug resistance by co-encapsulation of doxorubicin and curcumin in chitosan/ poly(butyl cyanoacrylate) nanoparticles. Int J Pharm. 2012;426(1-2):193-201.

14. Notarbartolo M, Poma P, Perri D, Dusonchet L, Cervello M, D’Alessandro N. Antitumor effects of curcumin, alone or in combination with cisplatin or doxorubicin, on human hepatic cancer cells. Analysis of their possible relationship to changes in NF-kB activation levels and in IAP gene expression. Cancer Lett. 2005;224(1):53-65.

15. Barui S, Saha S, Mondal G, Haseena S, Chaudhuri A. Simultaneous delivery of doxorubicin and curcumin encapsulated in liposomes of pegylated RGDK-lipopeptide to tumor vasculature. Biomaterials. 2014; 35(5):1643-56. 